International Journal of Agriculture, Environment and Bioresearch

Vol. 5, No. 05; 2020

ISSN: $2456-8643$

\title{
COMPARATIVE ASSESSMENT OF SELECTED ERODIBILITY INDICES FOR EROSION PREDICTION OF SOILS OF IMO STATE, SOUTHEAST, NIGERIA
}

\author{
${ }^{1}$ Madubuike, C. N., ${ }^{1,2}$ Nwachukwu, P. I., ${ }^{3}$ Emerson, K. U. and ${ }^{2}$ Asuzu, C. C. \\ ${ }^{1}$ Department of Agricultural and Bio-resources Engineering, Federal University of Technology Owerri, Nigeria \\ ${ }^{2}$ Imo State Polytechnic Umuagwo-Ohaji, Owerri, Imo State, Nigeria \\ ${ }^{3}$ Civil Engineering and Geosciences, Newcastle University, United Kingdom
}

https://doi.org/10.35410/IJAEB.2020.5563

\begin{abstract}
A performance evaluation of selected erodibility indices for erosion prediction of soils of Imo State, Nigeria, was performed. Soil samples were collected from 12 locations across three regions of Imo State (Owerri, Okigwe and Orlu), using completely randomized design. Samples were analysed for erodibility indices: modified clay ratio (MCR), clay ratio (CR), dispersion ratio (DR), and erosion ratio (ER), alongside selected physicochemical properties. Results indicated that the soils are predominantly sand. Soils of Owerri region are loamy sand texture, while Okigwe and Orlu regions are Sandy loam and Sand textured respectively. Bulk density of soils ranged from $1.50 \mathrm{Mg} / \mathrm{m} 3 \square 1.81 \mathrm{Mg} / \mathrm{m} 3$, while soil organic matter (SOM) averages $2.27 \%$ for Owerri and Orlu, and $0.92 \%$ for Okigwe respectively. MCR varied across the various locations in the order of Orlu (65.23 $\square 80.01)>$ Okigwe (43.11 $\square 55.30)>$ Owerri $(15.20 \square 35.65)$ regions. Least DR (0.58) and ER (0.44) were recorded in Owerri region, while highest values of 0.99 and 0.91 were recorded in Orlu region. A simulated rainfall intensity of $165 \mathrm{~mm} / \mathrm{hr}$ resulted in 1.2 ton/ha and 6.6 ton/ha annual soil loss for Owerri and Orlu respectively. Soils of Owerri region were considered less susceptible to erosion because of their loamy sand textured nature and relatively high organic matter content. All the erodibility indices showed positive correction with soil loss. MCR was most positively $(\mathrm{R} 2=0.7579)$ correlated, followed by $\mathrm{ER}(\mathrm{R} 2=0.7279)$, while DR and CR showed slightly lower correlation with soil loss, with R2 values of 0.7056 and 0.7279 respectively.
\end{abstract}

Keywords: Erodibility, rainfall simulation, soil loss, textural class, Organic matter, Orlu

\section{INTRODUCTION}

Soil erosion takes place when soil particles are carried away by water or wind and deposited somewhere else. Erosion starts when rain or irrigation water detaches soil particles [1]. Soil erosion is the most widespread form of land degradation worldwide [2]. According to [3], soil erosion as a part of soil degradation is the decline in quality and quantity of a soil, which may be a function of various processes including erosion, contamination, drainage, acidification, laterization and loss of soil structure or a combination of these.

Soil Erodibility is an estimate of the ability of soil to resist erosion based on the physical characteristics of each soil. Generally, soils with faster infiltration rates, higher levelsof organic matter and improved structure have a greater resistance to erosion [4]. In Erodibility studies and 
the development of erosion models, numerous publications on the effect of soil properties in erosion processes have assisted in better quantifying and defining soil Erodibility [1].

Several indices of soil Erodibility have been developed by soil scientist and engineers to predict the susceptibility of soil to erosion, but a unified model for soil loss prediction is yet a challenge [5]. This major setback is as result of certain limitation such as location, soil type, and climatic factors, annual as well as seasonal rainfall associated with the parameters of measurement. This brought about the emergence of various indices to measure soil Erodibility such that will satisfy the condition of a particular region or area of choice under study.

Erodibility indices like dispersion ratio, clay ratio, modified clay ratio and erosion ratio have been employed by different researchers to assess the soil Erodibility. However, very little information is available on the Erodibility indices for the soils of submontaneous tract of Nigeria, particularly under different land uses and in relation to runoff and soil loss [6].

The Universal Soil Loss Equation which is an acclaimed general equation to measure soil loss is not actually universal. This is because some factors of the equation are widely dependent on the location, soil type or class, cropping practices and conservation practices, needing further evaluation of the various indices prior to application in a particular study area [7].

Soil characteristics influencing soil Erodibility are infiltration capacity and structural stability. These are largely influenced by soil texture, organic matter and soil plasticity. High infiltration capacity means that less water will be available for runoff and the surface is less likely to be ponded and more susceptible to splashing. In particular, soils which are highly permeable (e.g. sandy soils) have high infiltration capacities and are more prone to water erosion since the soil easily allows water to penetrate and therefore easily washed away. On the other hand, stable aggregates resist the beating action of rain and thereby save soil, even though runoff may occur. The factors that determine aggregate stability include bulk density, Atterberg limits as well as texture and organic matter content of soils [8].The organic and chemical constituents of the soil are important because of their influence on stability of aggregates as well as other activities of man. Soils with less than $2 \%$ organic matter can be considered erodible [9]. Most soils contain less than $15 \%$ organic content and many of the sands and sandy loams have less than $2 \%$. It is, however, suggested that soil Erodibility decreases linearly with increasing organic content over the range of 0 to $10 \%$ [10].

In Nigeria, the eastern region is where many cases of erosion and its devastating effects are common. Efforts are still underway to reclaim areas that have been ravaged by flood and properties washed away by erosion. Prediction tools that will help to obtain first-hand information on the extent of susceptibility of soil to erosion remain a challenge to the people of this region.Imo State is second in rank among states that are worst hit by erosion which is orchestrated by the type of soil present in some parts of the State.

For effective conservation planning and sustainability, quantification of soil loss and delineation of degraded areas is necessary [11]. However, [12] opined that erosion from field plots needs to be studied for periods generally well in excess of 5 years if satisfactory direct measurement of soil erodibility is to be obtained. However, direct measurement of soil erodibility requires longterm erosion plot studies, which are time-consuming and costly [13].It is therefore necessary to develop alternative simple and reliablemeans of estimating soil erodibility. Thus, the objective of this study was to perform a comparative assessment of selected erodibility indices for erosion prediction of soils of Imo State, in Southeast Nigeria. This was achieved by identifying the 
Vol. 5, No. 05; 2020

ISSN: $2456-8643$

various soil textural class in Imo State, evaluating selected indices for measurement of Erodibility, and a comparative assessment of the selected indices for erosion prediction.

\section{MATERIALS AND METHODS}

\section{Study area}

Imo state is located in the south eastern part of Nigeria and lies between Latitude $5^{\circ} 29^{\prime}$ North and Longitude $7^{\circ} 2^{\prime}$ East. The study area lies in the humid tropic with high relative humidity, atmospheric temperature, and rainfall. The mean annual atmospheric temperature ranges from 28oC-31oC with February and April as the hottest months [14]. Mean annual rainfall range from $2500 \mathrm{~mm}-3000 \mathrm{~mm}$ with the highest intensity between April and November [14]. The study locations covers three regions of Imo State: Owerri region, comprising Ihiagwa Owerri West, Obinze Owerri West, Onicha-Ezinihitte, and Obazu Mbieri; Okigwe region, comprising OkweOnuimo, Okwelle-Onuimo, Ugiri-Isiala Mbano, and Ezinnachi-Okigwe; and Orlu region, comprising Isiekenesi-Ideato, Umuna-Orlu, Umuagwo-Ohaji, and Umuokanne-Ohaji respectively.

\section{Soil sampling}

Soil samples were collected using completely randomized design. Triplicate samples were collectedfrom $0 \square 20 \mathrm{~cm}$ depth in each location and across the 12 study areas in Imo State, namely: Ihiagwa Owerri West, Obinze Owerri West, Onicha-Ezinihitte, Obazu Mbieri, OkweOnuimo, Okwelle-Onuimo, Ugiri-Isiala Mbano, Ezinnachi-Okigwe, Isiekenesi-Ideato, UmunaOrlu, Umuagwo-Ohaji, and Umuokanne-Ohaji respectively,using an Edelma soil auger. The soils were placed in properly labeled black polythene bags for the prevention of sunlight. Samples were transported to the Agricultural and Bio-resources Laboratory of Federal University of Technology Owerri (FUTO), Nigeria, for analyses.

\section{Determination of selected soil parameters}

Soil particle size (sand, silt, and clay) distribution was determined by the hydrometer methods as described by Gee and Or (2002)[15], bulk density by the core method (Blake and Hartge, 1986)[16], while soil $\mathrm{pH}$ was determined by using glass electrode.

Soil organic matter (SOM) was determined based on the procedure given in soil mechanics for road engineering [17]. This method estimates soil organic matter based on gravimetric weight change associated with high temperature oxidation of organic matter. The method is suitable for soils which contain little or no clay or chalky material. A sample of soil weighing $20 \mathrm{~g}$ was oven dried at $105 \mathrm{oC}$. The oven dried soil sample was placed in a crucible and heated in a muffled furnace at $360 \mathrm{oC}$ for about $2 \mathrm{hrs}$. The crucible with the soil sample was allowed to cool in a desiccator, and its weight determined to $0.001 \mathrm{~g}$. The percentage weight loss during the ignition step is reported as OM loss on ignition (LOI) with a method detection limit of $0.05 \%$.

Loss on ignition $($ percentage organic matter $)=\left(\mathrm{W} \_2-\mathrm{W} \_3\right) /\left(\mathrm{W} \_2-\mathrm{W} \_1\right) \times 100 \%$ 
where

W_1= weight of crucible

W_2= weight of crucible + oven dried soil

W_3= weight of crucible + soil after cooling

\section{Erodibility indices}

Clay ratio [4], modified clay ratio [4], dispersion ratio [18], and erosion ratio [19] were determined using the following equations:

Clay Ratio $(C R)=\frac{(96 \text { Sand }+\% \text { Silt })}{\$ 6 \text { Clay }}$

Modified Clay Ratio $(M C R)=\frac{\% \text { sand }+\% 6 \text { silt }}{\% \text { clay }+\% \text { organic matter }}$

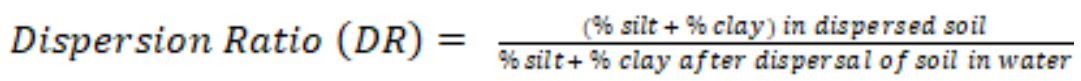

Erosion Ratio $(E R)=\frac{\text { Dispersion ratio }}{\text { colloid content moisture equivalent ratio }}$

\section{Rainfall Simulation}

A rainfall simulator was constructed and used to estimate soil loss because storm characteristics and nature of natural rainfall are usually unreliable, and may vary across the different locations. As a result, it may take a much longer period to collect equivalent amount of data as could be obtained from a single rainfall simulation exercise [20].

The rainfall simulator used in this study followed the principle of a modified Meeuwig drip-type simulator [21], having a drop fall height of $1.5 \mathrm{~m}$. At a simulated intensity of $165 \mathrm{~mm} / \mathrm{hr}$, the approximate water drop size was $2.5 \mathrm{~mm}$. Raindrop size from height less than $1.5 \mathrm{~m}$ will likely result to less kinetic energy and reduced the terminal velocity of the simulated rainfall. This is in agreement with the work by [22] whose drop fall height was $1.66 \mathrm{~m}$. At this height, larger drops attained $70-75 \%$ and smaller drops up to $90 \%$ of their terminal velocities [23].

In each location, a plot size, devoid of vegetation and measuring $1.5 \mathrm{~m} \times 1.5 \mathrm{~m}$, was selected. The soil bin $1.3 \mathrm{~m} \times 0.9 \mathrm{~m}$ was gently pressed into the soil surface using a hammer, and ensuring minimal disturbance of the soil. The rainfall simulator was positioned above the soil bin. The down slope of the soil bin frame was open to allow the movement of runoff and detached sediment onto a collection tray which channeled the runoff and eroded sediment into a collection can. The area of the soil bin was made larger than area covered by the simulated rainfall.

The simulation test was performed in the 12 selected locations and under 3 different soil conditions of Dry run (DR), Wet run (WR), and Saturated run (SR) respectively. The Dry run 
involved performing the test at field moisture state (in situ) of the soil. The Wet run was performed 6-10 hrs after the Dry run. The Saturated run was carried out $1 \mathrm{hr}$ after the Wet run, when the soil is saturated or near saturation state.Each simulation test was performed for 45 minutes. The soil losses obtained at the end of the simulation tests were taken to the laboratory, dried and weighed to quantify the amount of soil loss from respective locations under the various runs.

\section{RESULTS AND DISCUSSION}

Particle size distribution

Table 1. Textural class and selected soil properties across study locations

\begin{tabular}{|c|c|c|c|c|c|c|c|c|c|}
\hline \multirow[b]{2}{*}{ Location } & \multicolumn{3}{|c|}{ Texture } & \multirow{2}{*}{$\begin{array}{l}\text { Textural } \\
\text { Class }\end{array}$} & \multirow[b]{2}{*}{$\mathrm{pH}$} & \multirow{2}{*}{$\begin{array}{l}\mathrm{BD} \\
\left(\mathrm{Mg} / \mathrm{m}^{3}\right)\end{array}$} & \multicolumn{2}{|c|}{ SOM (\%) } & \multirow{2}{*}{$\begin{array}{l}\mathrm{OM} \\
\text { rating* }\end{array}$} \\
\hline & $\begin{array}{l}\% \\
\text { Sand }\end{array}$ & $\begin{array}{l}\% \\
\text { Silt }\end{array}$ & $\begin{array}{l}\% \\
\text { Clay }\end{array}$ & & & & SOM & SD & \\
\hline $\begin{array}{ll}\text { Ihiagwa } & \text { Owerri } \\
\text { West } & \end{array}$ & 81 & 17 & 2 & Loamy sand & 8.01 & 1.63 & 2.5 & 0.090 & $\begin{array}{l}\text { Very } \\
\text { high }\end{array}$ \\
\hline $\begin{array}{l}\text { Obinze } \\
\text { West }\end{array}$ & 81 & 17 & 2 & Loamy sand & 7.98 & 1.57 & 1.84 & 0.098 & High \\
\hline Onicha Ezinihitte & 81 & 17 & 2 & Loamy sand & 8.04 & 1.50 & 2.4 & 0.040 & $\begin{array}{l}\text { Very } \\
\text { high }\end{array}$ \\
\hline Obazu Mbieri & 82 & 16 & 2 & Loamy sand & 8.02 & 1.58 & 2.35 & 0.050 & $\begin{array}{l}\text { Very } \\
\text { high }\end{array}$ \\
\hline Okwe Onuimo & 65 & 25 & 10 & Sandy loam & 6.75 & 1.74 & 0.77 & 0.020 & Very low \\
\hline Okwelle Onuimo & 66 & 24 & 10 & Sandy loam & 6.48 & 1.74 & 0.71 & 0.046 & Very low \\
\hline Ugiri Isiala Mbano & 68 & 22 & 10 & Sandy loam & 6.64 & 1.75 & 1.04 & 0.040 & Low \\
\hline Ezinnachi Okigwe & 70 & 20 & 10 & Sandy loam & 6.47 & 1.73 & 1.16 & 0.020 & Low \\
\hline $\begin{array}{l}\text { Isiekenesi Ideato } \\
\text { South }\end{array}$ & 89 & 9 & 2 & Sand & 8.56 & 1.79 & 1.55 & 0.140 & Medium \\
\hline Umuna Orlu & 89 & 9 & 2 & Sand & 8.60 & 1.81 & 1.34 & 0.120 & Medium \\
\hline Umuagwo Ohaji & 88 & 10 & 2 & Sand & 8.43 & 1.79 & 3.95 & 0.065 & $\begin{array}{l}\text { Very } \\
\text { high }\end{array}$ \\
\hline Umuokanne Ohaji & 88 & 10 & 2 & Sand & 8.43 & 1.81 & 2.24 & 0.220 & High \\
\hline
\end{tabular}


Vol. 5, No. 05; 2020

ISSN: $2456-8643$

*Murphy et al. (2012)

Key: $\mathrm{BD}=$ Bulk density; $\mathrm{SOM}=$ Soil organic matter; $\mathrm{SD}=$ Standard deviation

Results of textural analysis presented in Table 1 show that soils of the various locations are dominated by sand fraction $(65 \square 89 \%)$, followed by silt $(9 \square 25 \% 0$, and relatively small clay fractions $(2 \square 10 \%)$. Soils of Owerri region, comprising locations in Ihiagwa Owerri West, Obinze Owerri West, Onicha Ezinihitte, and Obazu Mbieri can be classified as Loamy sand textured. Similarly, Okwe Onuimo, Okwelle Onuimo, Ugiri Isiala Mbano, and Ezinnachi Okigwe soils are Sandy loam textured. Locations in Isiekenesi Ideato South, Umuna Ohaji, Umuagwo Ohaji, and Umuokanne Orluare sand texture category, resulting from their very high

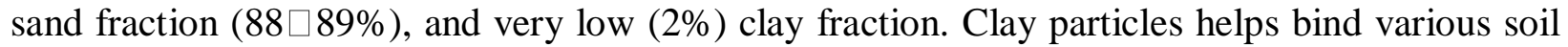
fractions to form more stable aggregates that provides increased resistance to erosion. The absence of clay, on the other hand, decreases the tendency for soil aggregates to resist erosion by water. Similarly, sand to clay ratio was highlighted as the main physical factor controlling the aggregate stability against erosion [31], while increase in the sand fraction in soils have been reported to decrease the susceptibility of soils to gully erosion [24].

\section{Soil pH}

The soil $\mathrm{pH}$ of the study locations ranged from slightly acidic to slightly basic. Soils of the Loamy sand category show considerably lower $\mathrm{pH}$ than the other soil type. Soils in the Okigwe locations, comprising Okwe Onuimo, Okwelle Onuimo, Ugiri Isiala Mbano, and Ezinnachi

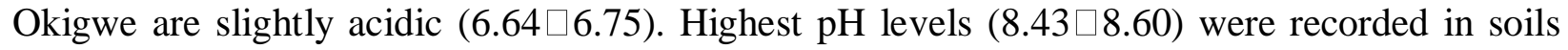
from the Orlu locations, comprising Isiekenesi Ideato South, Umuna Orlu, Umuagwo Ohaji, and Umuokanne Ohaji. These soils are sand textured. Soils from the Owerri locations are also slightly basic. According to [25], soil $\mathrm{pH}$ is closely related to the type of soil nutrient and their availability. The $\mathrm{pH}$ distribution of soils from the various locations also indicated a relationship between the soil texture and the $\mathrm{pH}$. The Sandy loam textured soils are slightly acidic, while the Loamy sand and Sand textured soils are slightly basic in nature.

\section{Soil bulk density}

The bulk density of the soils range from $1.50 \square 1.81 \mathrm{Mg} / \mathrm{m} 3$. Highest bulk densities $(1.79 \square 1.81$ $\mathrm{Mg} / \mathrm{m} 3$ )were recorded in the Sand textured soils from Orlu region, while the least densities $(1.50 \square 1.63 \mathrm{Mg} / \mathrm{m} 3)$ were recorded among the Loamy sand textured soils of Owerri region. Soils from Okigwe region (Okwe Onuimo, Okwelle Onuimo, Ugiri Isiala Mbano and Ezinnachi Okigwe) recorded an average bulk density of $1.74 \mathrm{Mg} / \mathrm{m} 3$, with very small variations in their density values. The relatively high bulk density of the soils of Orlu region could be attributed to their higher soil OM content, as compared to soils from other regions. Bulk density is a combined effect of soil texture, structure, organic carbon and applied pressure on soil [26], [27]. It is important in the estimation of certain physical soil properties, such as porosity, water retention, heat capacity, and compressibility [28]. According to [29], bulk density is an important parameter in relation to erosion by water because it reflects the extent of compaction, cohesiveness and structural development of soils.

\section{Soil organic matter}


Results of soil OM show that locations in Owerri and Orlu regions recorded higher organic matter percentages $(1.34 \square 3.95 \%)$, while soils of Okigwe region showed the least $(0.71 \square 1.04 \%)$ soil OM. Following to the ratings by Murphy et al. (2012) [30], soils of Owerri region have high to very high OM rating, owing to their textural class. Soils of Orlu region have medium to very high OM rating, while soils of Okigwe region have very low to low OM rating. According to [1], the organic and chemical components of the soil are significant because of their role on stability of aggregates. Soil OM has a profound effect on the soil due to its ability to bind soil particles together. [32] reported that soils containing high OM are resistant to soil crusting and favours crop yields and root development. Hence, by its binding potential, OM helps to stabilize loose soils against soil erosion. On the other hand, low OM content of soils is an indication of poor aggregate stability which predisposes the soil to dispersion and erosion [33].

Relationship betweenerodibility indices, soil loss and selected soil parameters

Table 2 shows the amount of soil loss from the dry run, wet run and saturated run, alongside the erodibility indices across the various study locations. Analysis of variance indicated nonsignificant difference $(\mathrm{P}<0.05)$ among the three simulated runs. This implies that different moisture states of the soils in the study locations do not significantly affect their susceptibility, or otherwise, to erosion by water.

Table 2. Soil loss of various runs and erodibility indices across study locations

\begin{tabular}{|llllllll|}
\hline \multirow{2}{*}{ Location } & \multicolumn{9}{l}{ Soil loss (tons/ha/yr) } & \multicolumn{7}{l|}{ Erodibility indices (\%) } \\
\cline { 2 - 8 } & DR & WR & SR & MCR & CR & DR & ER \\
\hline Ihiagwa Owerri West & 1.69 & 1.42 & 1.11 & 15.2 & 14.21 & 0.58 & 0.44 \\
Obinze Owerri West & 1.27 & 1.18 & 1.06 & 30.25 & 25.41 & 0.71 & 0.53 \\
Onicha Ezinihitte & 1.86 & 1.64 & 1.48 & 25.55 & 20.14 & 0.65 & 0.48 \\
Obazu Mbieri & 1.65 & 1.36 & 0.99 & 35.65 & 30.25 & 0.71 & 0.57 \\
Okwe Onuimo & 3.95 & 3.71 & 3.52 & 47.11 & 35.72 & 0.76 & 0.73 \\
Okwelle Onuimo & 3.5 & 3.09 & 2.59 & 43.11 & 33.62 & 0.73 & 0.65 \\
Ugiri Isiala Mbano & 2.3 & 2.02 & 1.73 & 50.21 & 40.23 & 0.81 & 0.77 \\
Ezinnachi Okigwe & 3.7 & 2.96 & 2.59 & 55.3 & 43.22 & 0.85 & 0.81 \\
Isiekenesi Ideato South & 7.46 & 7.17 & 5.18 & 65.23 & 47.65 & 0.9 & 0.86 \\
Umuna Orlu & 7.42 & 6.17 & 5.55 & 73.22 & 53.21 & 0.93 & 0.88 \\
Umuagwo Ohaji & 7.1 & 6.05 & 5.49 & 77.1 & 55.25 & 0.97 & 0.89 \\
Umuokanne Ohaji & 5.06 & 4.69 & 4.2 & 80.01 & 58.25 & 0.99 & 0.91 \\
\hline
\end{tabular}


Vol. 5, No. 05; 2020

ISSN: $2456-8643$

Key: $\mathrm{DR}=$ Dry run; $\mathrm{WR}=\mathrm{Wet}$ run; $\mathrm{SR}=$ Saturated run; $\mathrm{MCR}=$ Modified clay ratio $\mathrm{CR}=$ Clay ratio; $\mathrm{DR}=$ Dispersion ratio; $\mathrm{ER}=$ Erosion ratio

Figures 1-4 show the correlation of soil loss with MCR, CR, ER, and DR respectively.

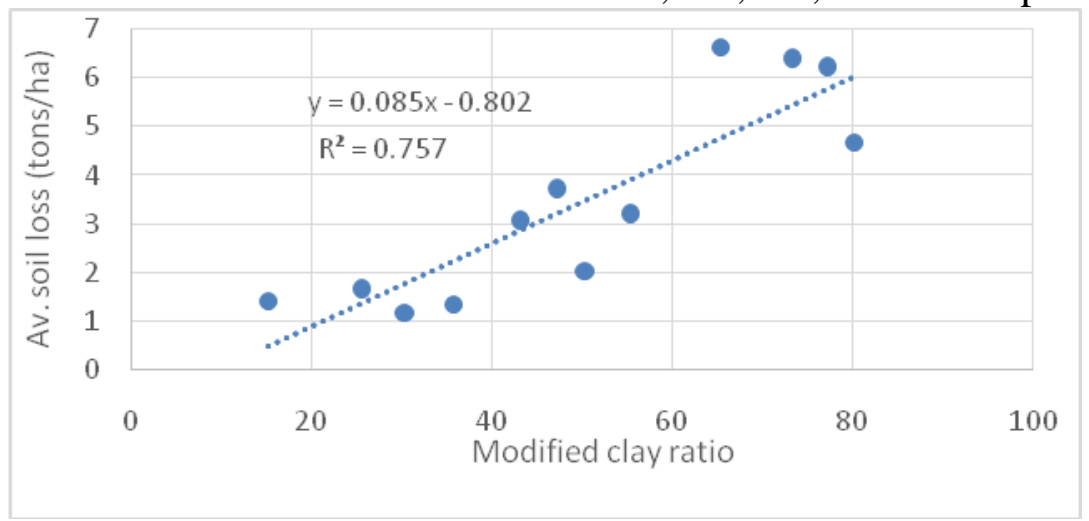

Figure 1. Correlation of soil loss with MCR

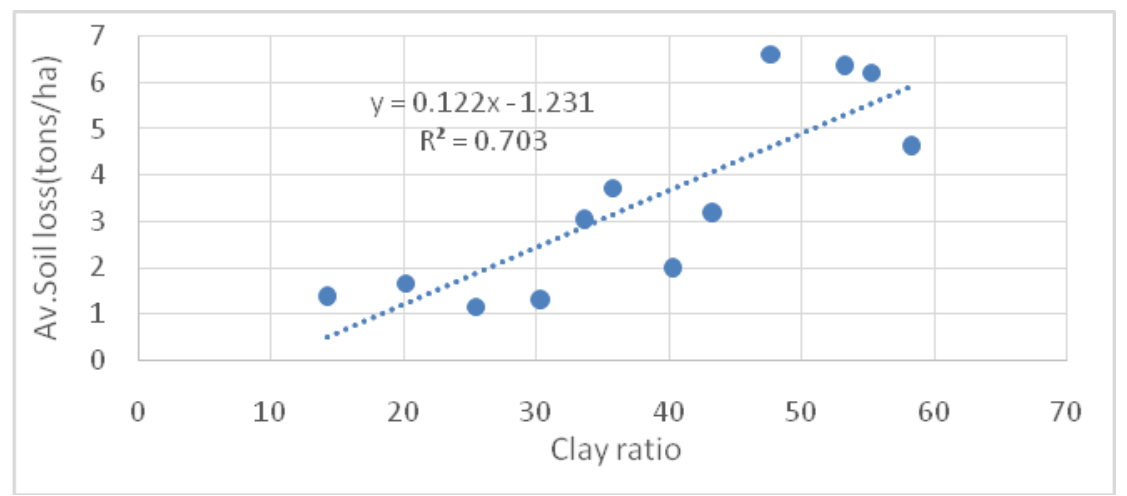

Figure 2. Correlation of soil loss with CR

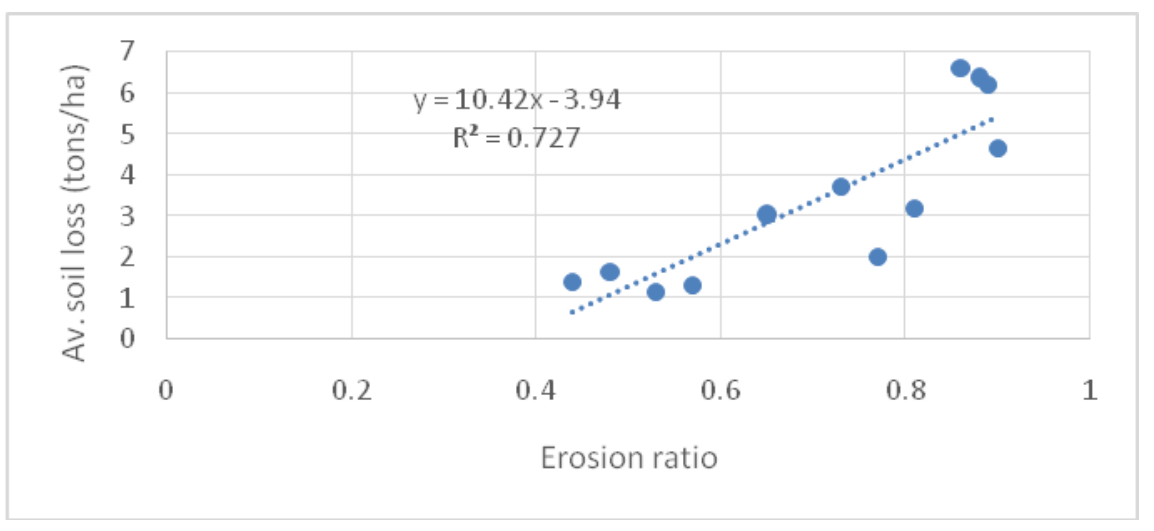

Figure 3. Correlation of soil loss with ER 
Vol. 5, No. 05; 2020

ISSN: $2456-8643$

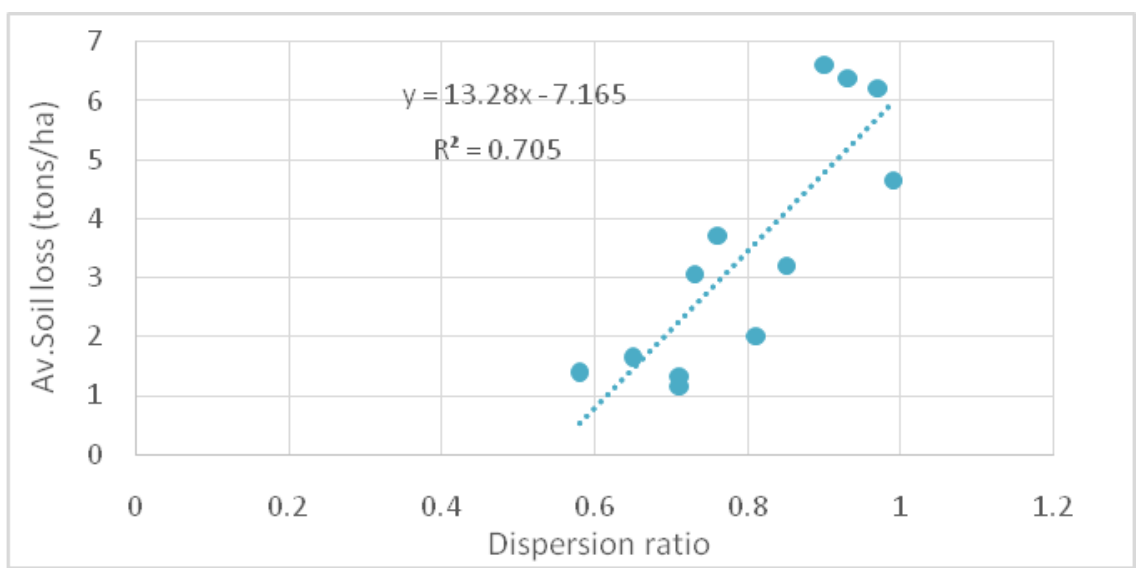

Figure 4. Correlation of soil loss with DR

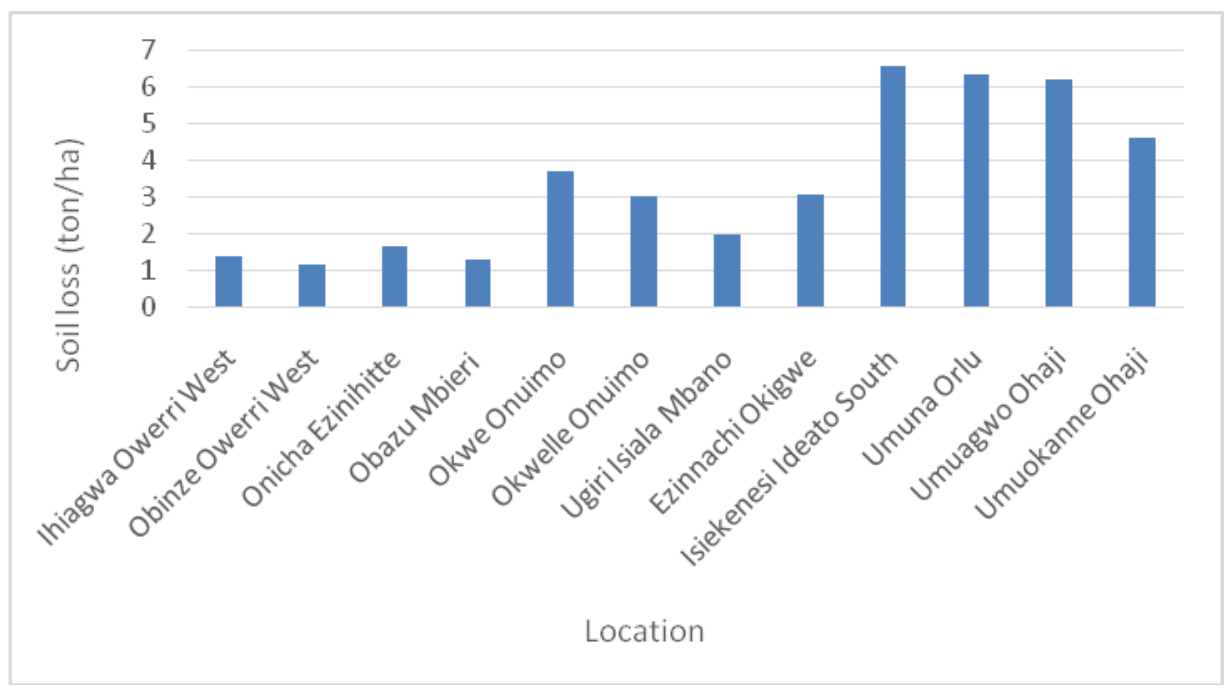

Figure 5. Average simulated soil loss of different locations

All the erodibility indices showed positive correction with soil loss. MCR was most positively $(\mathrm{R} 2=0.7579)$ correlated with soil loss, followed by ER $(\mathrm{R} 2=0.7279)$, while DR and CR showed slightly lower correlation with soil loss, with $\mathrm{R} 2$ values of 0.7056 and 0.7279 respectively.

Figure 5 shows the average soil loss from the different locations. Highest soil losses (4.7 $\square 6.6$ ton/ha) were recorded in soils of the Orlu region (comprising Isiekenesi-Ideato, Umuna-Orlu, Umuagwo-Orlu, and Umuokanne-Orlu respectively), with the highest soil loss occurring in Isiekenesi-Ideato. These soils were Sand textured and contained small (2\%) clay, a situation that could affect their ability to form strong aggregates that would resist erosion. The presence of clay materials is known to provide bondage between individual soil aggregates, leading to the formation of more stable aggregates that are less susceptible to erosion. The absence, or 
insufficient clay materials diminishes the tendency for the soil particles to bind strongly and form aggregates that will resist the shearing force of flowing water. These findings agree with the report of [8]who observed that soils with more sand and silt proportions than clay at the surface cap promote runoff, and are hence erodible. This could explain why the soils in this region have higher soil loss for the same simulated rainfall event than soils from the other experimented sites.

Figure 5 also shows that least soil losses (1.2 $\square 1.4$ ton/ha) were recorded in soils of Owerri location (comprising Ihiagwa Owerri West, Obinze Owerri West, Onicha-Ezinihitte, and Obazu Mbieri respectively), with the least (1.2 ton/ha) soil loss occurring in Onicha-Ezinihitte. Soils of Okigwe region (comprising Okwe-Onuimo, Okwelle-Onuimo, Ugiri-Isiala Mbano, and Ezinnachi-Okigwe) showed relatively higher (2.0 $\square 3.7$ ton/ha) soil losses compared to Owerri region, but lower than soil losses of Orlu region. The relatively low soil losses recorded at the Owerri region could be attributed to their textural class (Loamy sand) and relatively high OM content. Soil OM has a binding effect on soil and helps to stabilize loose soils against erosion by enhancing soil aggregate stability. Hence, in the absence of sufficient clay particles, SOM can help promote a soil's resistance to erosion. It also helps to promote infiltration and water holding capacity of soils, reducing the volume of surface runoff that could trigger soil erosion.

\section{CONCLUSION}

A study of soils across 12 locations in Imo State indicated that the soils are predominantly sand, with clay and silt ranging from $2 \square 10 \%$ and $9 \square 25 \%$ respectively. Soil loss investigation under different soil moisture conditions of dry run, wet run and saturated run showed no significant difference $(\mathrm{P}<0.05)$ in soil loss among the three simulated runs. All the erodibility indices showed positive correction with soil loss. MCR was most positively $(\mathrm{R} 2=0.7579)$ correlated, followed by ER ( $2=0.7279)$, while DR and CR showed slightly lower correlation with soil loss, with R2 values of 0.7056 and 0.7279 respectively. Relative resistance of soils to erosion was attributed to the soil textural class and inherent level of soil organic matter.

\section{REFERENCES}

[1]Idah, P.A., H. I. Mustapha, J. J. Musa and J. Dike. (2008). Determination of Erodibility Indices of Soils in Owerri West Local Government Area of Imo State, Nigeria. AU J.T. 12(2): 130-133.

[2] Bridges, E. M. and Oldeman, L. R. (1999). Global assessment of humaninduced soil degradation. Arid Soil Res Reh. 13:319-325.

[3]Boardman, J. (2006). Soil erosion science: Reflections on limitations of current approaches. Retrieved @ https//www.researchgate.net/publication/222072775_soil_erosion_science Reflections_n_the_limitations_of_current_appoches.

[4] Ezeabisili, A. C. C., Okoro B. U. and Emengini E. J. (2014). Relative Erodibilities of some soils from Anambra basin Sky journal of Soil and Environmental Management 3(8): pp 83-90 ISSN 2315-8794. 
[5]Baja Submanyan, Nurmiaty and Samsu Arif, (2014). GIS Based Soil Erosion Modelling for Assessing Land sustainability in the urban Watershed of Tallo River, South Sulawesi, Indonesia. Modern Applied Science 8(4): ISSN 1913-1844.

[6]Singh, M. J. and Khera, K. L. (2008). Soil Erodibility Indices under Different Land Uses in Lower Shiwalks. Tropical Ecology journal 49(2):113-119.

[7]Arnold, R. W., Szabolcs, I. and Targulian, V. O. (1990). Global Soil Change. Report of an IISA-ISSS-UNEP task force on role in global change.

[8]Toy, J. T., George, R. F., and Kenneth, G. R. (2002). Soil erosion. New York (NY): Wiley.

[9]Ekwue, E. I. (1990). Organic matter effect on soil strength properties. Soil and Tillage Research, 16: 289-297.

[10]Morgan, R.P.C. 2001. A simple approach to soil loss prediction: a revised MorganMorgan-Finney model. Catena 44(4): 305-322.

[11]Yadav R, and Sidhu, G. (2010). Assessment of soil erosion in Himachal Pradesh. J. Indian Soc. Soil Sci., 58(2):212-220.

[12]Loch R. J, Slater, B. K. and Devoil C. (1998) Soil erodibility (Km) values for some Australian soils. Australian Journal of Soil Research, 36(6):1045-1056.

[13]Baruah, S., R. Kumaraperumal, B. Kannan, K. P. Ragunath and M.R. Backiyavathy (2019). Soil erodibility estimation and its correlation with soil properties in Coimbatore district. International Journal of Chemical Studies, 7(3): 3327-3332.

[14](NIMET) (2011). Nigeria Meteorological Agency. Seasonal Rainfall prediction and Socioeconomic implication in Nigeria. NIMET.

[15]Gee, G.W and Or (2002). Particle size analysis In:Dane, J.H, and G.C Topps (ed). Methods of Soil Analysis Part 4. Physical Properties. Soil Sci. Soc Am Book series 5. Madison, WI. Pp. 223-293.

[16]Blake, G. R. and Hartge, K. H. (1986). Bulk density. In: Methods of Soil Analysis. Part 1 (Ed. A. Klute). ASA Press, Madison, WI, USA.

[17]Road Research Laboratory (2008). Soil Mechanics Road Engineers vol.1 part 2 military Engineering. H.M. Stationery,University of Wisconsin - Madison

[18] Morgan, R. P. C., (1996) Soil erosion and conservation, Second edition, Blackwell Malden, pp. 75-89.

[19]Suresh, R. (2013). Soil and Water Conservation Engineering pp 223-333 Standard Publisher Distributors New Delhi India. 
[20]Schmid, G. L. (1988). A rainfall simulator study of soil erodibility in the Gallatin National Forest, Southwest Montana. A thesis submitted for the degree of Master of Science in Soils, Montana State University, Montana, Unpublished. Online. Available at https://www.google.com/search?client=opera\&q=erodibiity+study+using+rainfall+simulator\&so urceid=opera\&ie $=U T F-8 \& o e=U T F-8 \#$ Accessed 2020, Sept 18 .

[21]Meeuwig, R. O. (1971). Soil stability on high elevation rangeland in the intermountain area. USDA Forest Service Res. Paper INT-94.

[22]Bryan R. B. (1968). The development, Use and Efficiency of indices of soil Erodibility. Elsevier Publishing Company, Amsterdam. pp 5-26.

[23]Laws, J. O., (1941). Measurement of the fall velocity of water drops and rain drop. Transactions America geophysical union wiley online library.

[24]Ezochi, J. I. (2000). The influence of runoff, lithology, and water table on the dimensions and rate of gullying processes in eastern Nigeria. Elsevier, Catena verlage, Cremlingen.

[25]Deng Y S, Dong X, Cai C F, Ding S W. (2016). Effects of land uses on soil physic-chemical properties and erodibility in collapsing-gully alluvial fan of Anxi County, China. J Integr Agr. 15: $1863-1873$.

[26]Wolf, B. \& Snyder, G. H. (2003). Sustainable Soils. The Place of Organic Matter in Sustaining Soils and Their Productivity. Food Products Press, NewYork.

[27]Velayutham, M. (2012). Soils. In: Indian Council of Agricultural Research. 2012 Handbook of Agriculture, New Delhi.

[28]Ruehlmann, J. and Körschens, M. (2009). Calculating the Effect of Soil Organic Matter Concentration on Soil Bulk Density, Soil Science Society of America Journal: 73(3): 876-885.

[29]Heard, J. R., Kladivko, E. J. and Mannering, J.V. (1988). Soil macro porosity, hydraulic conductivity and air permeability of silty soils under long term conservation tillage in Indiana. Soil Tillage Research. 11: 1-8.

[30]Murphy, S., Giménez, D., Muldowney, L., Heckman, J. (2012), Soil organic matter level and interpretation [FS1136]. Rutgers, New Jersey Agricultural Experiment Station. http://njaes.rutgers.edu/pubs/publication.asp?pid=FS1136, Accessed 2020, September 16.

[31]Mbagwu, J. S. C. (2003). Environmental control of soil structure in Mediterranean soils. Lecture given at the college on soil physics. LNS0418023, pp. 255-259.

[32]Mbagwu, J. S. C. and Bazzoffi, P. (1998). Soil characteristics related to resistance of breakdown of dry soil aggregates by waterdrops. Soil Tillage Research. 45: 133-145.[33] Brady and Weil(2002). The Nature and properties of soil. Pearson, NY. 